\title{
Levelof Awareness among Professionals in the Nigerian Construction Industry on Public Private Partnership Procurement and Its Variants in Infrastructure Development in Nigeria: Case Study, Lagos State
}

\author{
${ }^{1}$ Ogunbiyi, Moses A., ${ }^{2}$ Owolabi, Sheriff Abiodun, ${ }^{1}$ Olawale, Simon. \\ ${ }^{3}$ Ojurongbe Taiwo A. \\ ${ }^{1}$ Department of Civil Engineering, Osun State University, Osogbo \\ ${ }^{2}$ Department Physical Planning, Osun State University, Osogbo \\ ${ }^{3}$ Departments of Mathematical and Physical Sciences, Osun State University, Osogbo
}

\begin{abstract}
This is a survey that investigates the awarenessof professionals and other participants in the Nigerian construction industry in the use of public private partnership and its variant methods in procuring infrastructure in Nigeria.The paper assesses the variants of PPP in infrastructure development, identifies the issues and benefits associated with PPP and factors that affect the choice of the variants. The study employs structured questionnaire to gather pertinent data from the consulting firms of practicing professionals and other practitioners in the built environment in Nigeria such as;

1. Quantity Surveyors;

2. Architects;

3. Engineers;

4. Builders.

5. Land Surveyors;

6. Lawyers.

Thereafter, stratified random and purposive sampling technique was used in the selection of respondents to the survey questionnaire. Result shows that Nigeria began to use PPP for project procurement in the mid to late 1990s and the trend is expected to continue into the future, with positive impact on the private and public sectors. The study also, finds that BOT a variant of PPP is the most commonly used with a mean weighted value of 6.78 or $68 \%$; ranked first with $28.4 \%$ of respondents. Followed by SC with $23.9 \%$; MC with $19.4 \%$; CC with 13.9\%; JVP with $10.5 \%$ and PFI with 4.5 respectively. This survey concludes that government should partner more with the private investors in the provision of infrastructure in the face of dwindling resources of government; it also recommends that;

1. PPP and its variants should be popularized through organized workshops and seminars;

2. Its advantages should be propagated to attract local and foreign investors;

3. PPP and its variants should be used to mitigate the challenges facing the traditional method of procurement of infrastructures.
\end{abstract}

Keywords: Private Public Partnership (PPP); Build Operate \& Transfer (BOT); Service Contracting (SC); Management Contracting (MC); Turnkey Project (TP); Private Finance Initiative (PFI); Joint Venture Partnership (JVP); Project Concession Contracting (PCC); Lagos State (L/S);

\section{INTRODUCTION}

Lucy (2001) Opined that public private partnership are means of using private finance and skillto deliver infrastructure projects traditionally provided by the public sector. This includes schools, hospitals, roads, and water facilities. Instead of the public sector body directly procuring capital assets and subsequently owning, operating and regulating them, PPPs generally involves the private sector owning and operating, but the public sector "buying" the service from the contractor for a fixed period of time. Matson (2006) Stated that public-Private
Partnership as a contractual agreement between a public agency (federal, state or local and a private sector entity). Through which agreement, the skills and assets of each sector (public and private) are shared in delivering a service or facility for the use of the general public.In addition to the sharing of resources, each party shares in the risks and rewards potential in the delivery of the service and or facility. Alfen et al., (2009) arguedthat public-private partnerships (PPPs) in infrastructure development involve private sector participation in any or all of the design, construction, financing and operation phases 
of a public utility infrastructure service or both. The capital-intensive nature of basic infrastructure and competition for limited government budgetary resources have prompted governments to invite private investors to fulfill the widening demandsupply gap for infrastructure while the governments are endeavoring tomeetthe social commitments within the fiscal constraints.Babatunde et al.(2010) reviewedthat public private partnerships (PPPs) are an attempt by government to tap from the enormous private resources by way of diversification and letting private investors partake in the provision of fundamental government responsibility of providing basic social and infrastructural amenities. Solomon (2006) suggested that public private partnership is an arrangement between the public and private sectors (consistent with a broad range of possible partnership structures) with clear agreement on shared objectives for the procurement and delivery of public infrastructure and/or public services by the private sector that would otherwise have been provided through traditional public sector procurement. Ellisabetta et al.(2007) argued that public-Private Partnerships (PPPs) is a long-term contractual arrangements between the public and private sectors in which the private sector have responsibility for significant aspects of the building and operation of an infrastructure for the delivery of public service

Olayiwola and Adeleye (2005) defined infrastructure as basic services without which primary secondary and tertiary productive activities cannot function. In its wider sense, infrastructural facilities embrace all public services from law and order through education and public health to transportation, communications and water supply. Kahn (2000) reviewed that infrastructural facilities can be classified into three main types; physical infrastructure such as roads, water, rural electrification, storage and processing facilities; social infrastructure namely; health and educational facilities, community centers, fire and security services; Institutional infra- structure which include credit and financial institutions, Agricultural research facilities. It is perceived that the adequate provisions of these types of infrastructures will enhance the introduction and adoption of innovations offered by institutional infrastructure.

Bernstein, (2003) stated that infrastructural development is a desirability of overcoming deprivation and low quality of rural life. It could also refer to the provision of bridges, hospitals, schools, electricity and potable water in areas where they are lacking. Rural infrastructural development is a positive action that aims to improve the welfare of the people. ESCAP(2009) opinedthat infrastructure refers to the sub-structure or underlying foundation or network used for providing goods and services; especially the basic installations and facilities on which the continuance and growth of a community, state, depend. Examples include roads, water systems, communications facilities, sewers, sidewalks, cable, wiring, schools, power plants, and transportation and communication systems.Also, Moteff and Partfomak (2004) postulatedthat infrastructure is the basic facilities, services, and installations needed for the functioning of a community or society, such as transportation and communications systems, water and power lines, and public institutions including schools, post offices, and prisons. Hence infrastructure is facilities with the common characteristics of capital intensiveness and high public investment at all levels of government. In OECD (2007), Infrastructure was described as not being an end in itself butrather, itis a means for ensuring the delivery of goods and services that promote prosperity and growth and contribute to qualityoflife, including the social well-being, health and safety of citizens, and the quality of their environments. Wikipedia online encyclopedia, (2011): Defined infrastructure as a set of interconnected structural elements that provide framework supporting an entire structure of development. It is an important term for judging a country or region's development.It is also a means of progression from a simpler or lower to a more advanced, mature, or complex form or stage. It is also defined as the gradual advancement or growth through a series of progressive changes. Development is a process, not a level. Itis a path to achieve certain goals. It is on this premise that the survey seeks to investigate the awareness of professionals in the Nigerian Construction industry on the use of PPP and its variant constituents.

\section{METHODOLOGY}

This phase deals with the development of questionnaire using the parameters in the study to develop well-structured and relevant questions. The survey approach was decided as the most appropriate for the needed data and data was collected by means of structured questionnaire and back up interview to clarify information supplied as need be. The questionnaire was considered to be very good method of gathering qualitative and quantitative information for this research. Its limitations include inflexibility in that it prevents the researcher from asking further questions, based on the fact that the intended respondent required to fill the questionnaire may not be the appropriate person needed for the research.

\section{Questionnaire Design}

The questionnaire was broken down into two parts. Section A deals with the general particulars of the respondents in terms of qualification (both education and profession), Organization types and year of experience of the 
respondent etc. section $\mathrm{B}$ deals with the research objectives which are as follows:

1. To identify and assess the variants of public private partnerships.

2. To identify the problems and benefits associated with public private partnerships.

3. To identify the factorsthat affect the choice of variants of public private partnerships.

Scale questions were used extensively in the questionnaire. These types of questions provide the respondent, with a number of options in order to score their responses on a scale. This gives ten options to the respondent for their responses.

\section{Population Sampling and Selection of Sample size}

Population means a large group from which a sample is taken. In order to ensure a reliable and adequate data to investigate the research problems generated, it is necessary to have a population sample, which is heterogeneous and comprehensive. It is also important that such a population gives a true representation of the target population. Samples are always the subset or small parts of the total number that could be studied. The study population within the context of this study is a database of relevant professionals in the construction industry, consulting firms and government parastatals.In the study of public private partnerships, infrastructure development in Nigeria views and assessment from groups of respondents are required. Only practicing quantity surveyors, architects, structural engineers, lawyers and builders fall within the class of the respondents for this research. Some of these respondents will include those that work with government parastatals, and the private owned construction professional firms. They are all required to respond to the questions raised by the questionnaire on the study of public private partnerships in infrastructure development in Nigeria.

The survey generates its sample size by using stratified random and purposive sampling techniques adopting Mendenhall et al (1997) formulae for calculating sample size for the study.

The formula is given as:

$$
\mathrm{n}=\frac{\mathrm{N} p q}{(\mathrm{~N}-1) \frac{\mathrm{B}^{2}}{4}+p q}
$$

Where ' $n$ ' is the sample size; ' $N$ ' is the population size, ' $B$ ' is the level of confidence level for error estimation $(=0.05)$, ' $p$ ' is the population proportion with required characteristics (assumed to be 0.5 ) and ' $q$ ' is the population proportion without the required characteristics $(q=1-p)$.
Substituting this value into the formula given, 72 samples of contractors and 30 percent of the figure are chosen given 25 samples for contracting firms. However for the client and public organization (consulting firms and government parastatals), purposive sampling was used and sample size of 75 were chosen. The total sample size (target population) for this research is 100 . This figure is based on 88 questionnaires and 67 duly completed and returned with 21 voided.

\section{Method of data collection and Analysis}

Akogun (2000) stressed the importance of research instrument as a necessary tool in order to realize the set objectives of a research.Means of obtaining data or information will be based on;

- Administering of research questionnaire to approved organizations, consulting firms, individuals to elicit respective views on the topic.

- Review of literature of renowned authors, research journals/seminars papers, occasional report, government publications interest, past thesis etc.

This was the basis of research tool that was employedby this study. The questionnaire was prepared for this study to askrelevant questions in an attempt to address the setobjectives.

The study on level of awareness of professionals and other stakeholders in public private partnerships and its variants in infrastructure development in Nigeria is such that will require percentage, frequency and mean weighted value. This was attempted to show how aware are professionals, contractors etc. on use of public private partnerships procurement in the provision of infrastructure development in Nigeria. Therefore, Mean Weighted Value; themethod of mean weighted value (MWV) was used in ranking of objectives questions asked by the structured questionnaire distributed to respondents. The premise of decisionis that the ranking with mean weighted value (MWV) is ranked 0 and others are in descending order.

\section{Mean Weighted Value $(\mathbf{M W V})=\quad$ TWV Where} $(\mathrm{TWV})=$ Total Weighted Value

$N$

$\mathrm{N}=$ Total number of Respondents; where MWV is the ranking used per column and TWV is the sample size for each rating and $\mathrm{N}$ the total sample size. Since a scale of 0 to 10 point scale will be used for the collection of data.

All tests will be carried out using 10\% level of significance; the basis of decision will be on the following premise: 
$0.00 \leq 0.30$ : Little or no significance;

$0.30 \leq \mathrm{R} \leq 0.50$ : Low importance;

$0.50 \leq \mathrm{R} \leq 0.70$ : Moderate importance;

$0.70 \leq \mathrm{R} \leq 0.90$ : High importance;

$0.90 \leq \mathrm{R} \leq 0.100$ : Very highly importance.

\section{Data Analysis}

Statistical Package for Social Sciences (SPSS) was used to analyze the data gathered by this research. The analysis was mainly descriptive and inferential statistics. Descriptive Statistics are statistical methods used to organize, tabulate, summarize and describe data, while the inferential statistics are methods which involve using data from sample to draw conclusions or make decision about a population. However, the statistical tools and methods pertinent to the analysis and reporting of the primary and secondary data that was collected in this research are frequencies, percentages and means item score (ranking).

Results

\section{RESULTS AND DISCUSSION}

Table 1: Distribution Questionnaire

\begin{tabular}{|l|l|l|}
\hline Responses & Frequency & Percentage \% \\
\hline Questionnaire Distributed & 88 & 88 \\
Questionnaire collected & 67 & 76 \\
Questionnairenot collected & 21 & 24 \\
\hline Total & $\mathbf{8 8}$ & $\mathbf{1 0 0 . 0 0}$ \\
\hline
\end{tabular}

\section{Demographic characteristics of Respondents}

Table 2: Respondents Sex

\begin{tabular}{|l|l|l|}
\hline Sex & Frequency & Percentage \% \\
\hline Male & 58 & 86.6 \\
Female & 9 & 13.4 \\
\hline Total & 67 & 100.0 \\
\hline
\end{tabular}

Table 3: Responding Consulting Firms

\begin{tabular}{|l|l|l|}
\hline Respondent Designation & Frequency & Percentage \% \\
\hline Architectural Firm & 11 & 16.4 \\
Building Firm & 4 & 6.0 \\
Civil Engineering Firm & 18 & 26.9 \\
Quantity Surveying Firm & 23 & 34.4 \\
Land surveying Firm & 7 & 10.4 \\
Law Firm & 4 & 6.0 \\
\hline Total & $\mathbf{6 7}$ & $\mathbf{1 0 0 . 0}$ \\
\hline
\end{tabular}

Table 4: Respondents Academic Qualification

\begin{tabular}{|l|l|l|}
\hline Academic Qualification & Frequency & Percentage \% \\
\hline B.Sc/B.Tech & 31 & 46.2 \\
HND & 22 & 32.8 \\
OND & 4 & 6.0 \\
LLB & 4 & 6.0 \\
M.Sc./M.Tech & 6 & 9.0 \\
\hline Total & $\mathbf{6 7}$ & $\mathbf{1 0 0 . 0}$ \\
\hline
\end{tabular}

\section{Professional Qualification of Respondents}

Table 5: Respondents Professional Qualification

\begin{tabular}{|l|l|l|}
\hline Professional Qualification & Frequency & Percentage \% \\
\hline MNIQS & 10 & 14.9 \\
MNSE & 6 & 9.0 \\
MNIOB & 5 & 7.5 \\
MNIA & 8 & 11.9 \\
MNIS & 1 & 1.5 \\
NBA & 4 & 6.0 \\
FNIQS & 2 & 3.0 \\
FNSE & 1 & 1.5 \\
\hline
\end{tabular}




\section{Part-B}

\begin{tabular}{|l|l|l|}
\hline FNIA & 2 & 3.0 \\
No Response & 28 & 41.8 \\
\hline Total & $\mathbf{6 7}$ & $\mathbf{1 0 0 . 0}$ \\
\hline
\end{tabular}

Identification and Examination of the various PPP and its Variants in Infrastructure Developmentin Nigeria

Table 8: Types of PPP/Variant engaged in Procurement of infrastructure in L/State

\begin{tabular}{|l|l|l|}
\hline Infrastructure & Frequency & Percentage \% \\
\hline Road & 23 & 34.3 \\
Telecommunication & 4 & 6.0 \\
Sea Port & 1 & 1.5 \\
Health Facilities & 1 & 1.5 \\
Educational Facilities & 13 & 19.4 \\
Housing & 27 & 40.3 \\
\hline Total & $\mathbf{6 7}$ & $\mathbf{1 0 0 . 0}$ \\
\hline
\end{tabular}

Table 9: Frequency and Ranking of types of infrastructure procured under PPP and its Variants in L/S

\begin{tabular}{|c|c|c|c|c|c|c|c|c|c|c|c|c|c|c|c|}
\hline \multirow[b]{2}{*}{ Infrastructure } & \multicolumn{11}{|c|}{ Frequency } & \multirow{2}{*}{$\begin{array}{l}\text { TW } \\
\text { V }\end{array}$} & \multirow[t]{2}{*}{$N$} & \multirow[t]{2}{*}{ MWV } & \multirow[t]{2}{*}{ Rank } \\
\hline & $\mathbf{0}$ & 1 & 2 & 3 & 4 & 5 & 6 & 7 & 8 & 9 & 10 & & & & \\
\hline Road & 10 & 11 & 4 & 5 & 5 & 4 & 2 & 1 & 10 & 5 & 10 & 318 & 67 & 4.75 & 5th \\
\hline Electricity & 14 & 13 & 11 & 9 & 5 & 3 & 1 & 2 & 2 & 3 & 4 & 321 & 67 & 4.79 & 4th \\
\hline Water & 15 & 9 & 14 & 3 & 5 & 7 & 4 & 1 & 1 & 4 & 4 & 216 & 67 & 3.22 & 6th \\
\hline Telecom & 15 & 13 & 12 & 6 & 6 & 6 & 3 & 0 & 0 & 0 & 6 & 187 & 67 & 2.79 & 7th \\
\hline Railways & 22 & 11 & 11 & 4 & 2 & 7 & 0 & 3 & 0 & 1 & 6 & 178 & 67 & 2.66 & 8th \\
\hline Air port & 22 & 15 & 7 & 5 & 2 & 5 & 1 & 1 & 2 & 2 & 5 & 174 & 67 & 2.60 & 9th \\
\hline Sea port & 26 & 11 & 6 & 10 & 2 & 2 & 0 & 3 & 1 & 0 & 6 & 160 & 67 & 2.39 & 10th \\
\hline Health facilities & 4 & 7 & 9 & 2 & 5 & 7 & 5 & 9 & 7 & 5 & 7 & 350 & 67 & 5.22 & $3 \mathrm{rd}$ \\
\hline $\begin{array}{l}\text { Educational } \\
\text { facilities }\end{array}$ & 2 & 5 & 6 & 3 & 4 & 2 & 4 & 6 & 16 & 5 & 14 & 431 & 67 & 6.43 & 2nd \\
\hline Housing & 0 & 1 & 1 & 0 & 1 & 0 & 3 & 3 & 12 & 16 & 30 & 586 & 67 & 8.75 & 1 st \\
\hline
\end{tabular}

Table 10: Variants Mostly Used in Procuring Infrastructural Projects

\begin{tabular}{|l|l|l|}
\hline Variants of PPP & Frequency & Percentage \% \\
\hline Service Contract & 16 & 23.9 \\
Management Contract & 13 & 19.4 \\
Concession & 9 & 13.9 \\
Build Operate and Transfer (BOT) & 19 & 28.4 \\
Private Finance Initiative (PFI) & 3 & 4.5 \\
Joint Venture (JV) & 7 & 10.5 \\
\hline Total & $\mathbf{6 7}$ & $\mathbf{1 0 0 . 0}$ \\
\hline
\end{tabular}

Table 11: Level of Satisfaction in Negotiation and Execution of Projects Using the Variants

\begin{tabular}{|c|c|c|c|c|c|c|c|c|c|c|c|c|c|c|c|}
\hline \multirow[t]{2}{*}{ Variants of PPP } & \multicolumn{11}{|c|}{ Frequency } & \multirow[t]{2}{*}{ TWV } & \multirow[t]{2}{*}{$N$} & \multirow[t]{2}{*}{ MWV } & \multirow[t]{2}{*}{ Rank } \\
\hline & $\mathbf{0}$ & 1 & 2 & 3 & 4 & 5 & 6 & 7 & 8 & 9 & 10 & & & & \\
\hline Management Contracts & 1 & 3 & 6 & 5 & 9 & 10 & 6 & 11 & 8 & 6 & 4 & 387 & 67 & 5.78 & 4th \\
\hline Build Operate Transfer & 2 & 1 & 2 & 1 & 3 & 8 & 7 & 14 & 9 & 8 & 12 & 464 & 67 & 6.93 & $1 \mathrm{st}$ \\
\hline Affermage/Lease & 1 & 2 & 5 & 11 & 7 & 15 & 11 & 5 & 4 & 2 & 4 & 339 & 67 & 5.06 & 6th \\
\hline $\begin{array}{ll}\text { Private } & \text { Finance } \\
\text { Initiative } & \end{array}$ & 0 & 2 & 5 & 3 & 9 & 11 & 9 & 13 & 6 & 3 & 6 & 392 & 67 & 5.85 & $3 \mathrm{rd}$ \\
\hline Joint Venture (JV) & 2 & 0 & 2 & 0 & 7 & 12 & 17 & 10 & 9 & 4 & 4 & 412 & 67 & 6.15 & 2nd \\
\hline
\end{tabular}

Table 12: Initiators of Public Private Partnerships in Lagos State 


\begin{tabular}{|l|l|l|}
\hline Initiators & Frequency & Percentage \% \\
\hline Promoters & 4 & 6.0 \\
Investors & 22 & 32.8 \\
Contractors & 4 & 6.0 \\
Government & 36 & 53.7 \\
Operators & 1 & 1.5 \\
\hline Total & $\mathbf{6 7}$ & $\mathbf{1 0 0 . 0}$ \\
\hline
\end{tabular}

Table 13: Factors Affecting the Choice of PPP and its Variants

\begin{tabular}{|c|c|c|c|c|c|c|c|c|c|c|c|c|c|c|c|}
\hline \multirow{2}{*}{ Factors } & \multicolumn{11}{|c|}{ Frequency } & \multirow{2}{*}{$\begin{array}{l}\text { TW } \\
\text { V }\end{array}$} & \multirow[t]{2}{*}{$N$} & \multirow[t]{2}{*}{ MWV } & \multirow{2}{*}{$\begin{array}{l}\operatorname{Ran} \\
\mathbf{k}\end{array}$} \\
\hline & $\mathbf{0}$ & 1 & 2 & 3 & 4 & 5 & 6 & 7 & 8 & 9 & 10 & & & & \\
\hline Political stability of a country & 1 & 3 & 0 & 2 & 0 & 4 & 10 & 12 & 11 & 8 & 16 & 493 & 67 & 7.36 & 2nd \\
\hline $\begin{array}{l}\text { LegalRegulatory } \\
\text { Environment }\end{array}$ & 0 & 1 & 1 & 1 & 6 & 10 & 9 & 17 & 17 & 4 & 1 & 435 & 67 & 6.49 & 5 th \\
\hline $\begin{array}{l}\text { Financial and Technical- } \\
\text { feature of the Project }\end{array}$ & 0 & 0 & 1 & 1 & 4 & 6 & 12 & 14 & 8 & 9 & 12 & 486 & 67 & 7.25 & $3 r d$ \\
\hline Risk Allocation & 0 & 3 & 0 & 2 & 5 & 9 & 11 & 4 & 14 & 10 & 9 & 460 & 67 & 6.87 & 4th \\
\hline Government Policy & 0 & 1 & 1 & 1 & 1 & 11 & 9 & 6 & 10 & 12 & 15 & 498 & 67 & 7.43 & 1 st \\
\hline
\end{tabular}

Table 14: Important Factors considered by in theSelection of PPP Variants

\begin{tabular}{|l|l|l|}
\hline Important Factors Considered & Frequency & Percentage \% \\
\hline Political Stability of a country & 29 & 43.3 \\
The Legal Regulatory Environment & 7 & 10.3 \\
Government Policy & 9 & 13.4 \\
Financial and Technical Feature of a Project & 17 & 25.4 \\
Risk Allocation & 5 & 7.5 \\
\hline Total & $\mathbf{6 7}$ & $\mathbf{1 0 0 . 0}$ \\
\hline
\end{tabular}

Table 15: Problems Associated with Public Private Partnerships/VariantsProcurement

\begin{tabular}{|c|c|c|c|c|c|c|c|c|c|c|c|c|c|c|c|}
\hline \multirow[t]{2}{*}{ Associated Problems } & \multicolumn{11}{|c|}{ Frequency } & \multirow{2}{*}{$\begin{array}{l}\text { TW } \\
\text { V }\end{array}$} & \multirow[t]{2}{*}{$N$} & \multirow{2}{*}{$\begin{array}{l}\text { MW } \\
\text { V }\end{array}$} & \multirow{2}{*}{$\begin{array}{l}\text { Ran } \\
\mathbf{k}\end{array}$} \\
\hline & $\overline{\mathbf{0}}$ & $\mathbf{1}$ & 2 & 3 & 4 & 5 & 6 & 7 & 8 & 9 & 10 & & & & \\
\hline $\begin{array}{ll}\begin{array}{l}\text { Poor } \\
\text { methodology }\end{array} & \text { concession } \\
\end{array}$ & 1 & 1 & 5 & 3 & 6 & 14 & 10 & 9 & 8 & 3 & 7 & 398 & 67 & 5.94 & 4th \\
\hline Lack of preliminary study & 0 & 1 & 4 & 6 & 2 & 14 & 15 & 10 & 6 & 2 & 7 & 401 & 67 & 5.99 & $3 \mathrm{rd}$ \\
\hline $\begin{array}{l}\text { Absence of pre- } \\
\text { qualification }\end{array}$ & 0 & 1 & 8 & 9 & 10 & 16 & 5 & 3 & 8 & 4 & 3 & 345 & 67 & 5.15 & 9th \\
\hline Lack of adequate data & 0 & 0 & 3 & 4 & 11 & 15 & 15 & 8 & 4 & 5 & 2 & 380 & 67 & 5.67 & 6th \\
\hline Ineffective of Legal & 0 & 1 & 2 & 3 & 11 & 14 & 12 & 7 & 8 & 6 & 3 & 397 & 67 & 5.93 & 5 th \\
\hline Insufficient of Economic & 0 & 2 & 3 & 4 & 5 & 15 & 9 & 8 & 8 & 8 & 5 & 411 & 67 & 6.13 & 2nd \\
\hline Poor Environmental & 1 & 1 & 2 & 5 & 12 & 16 & 9 & 8 & 5 & 6 & 2 & 372 & 67 & 5.55 & 7 th \\
\hline Lack of Social & 0 & 1 & 4 & 5 & 17 & 9 & 10 & 10 & 4 & 1 & 6 & 368 & 67 & 5.49 & 8 th \\
\hline Inadequate of Technology & 1 & 0 & 1 & 2 & 10 & 17 & 7 & 10 & 7 & 3 & 9 & 418 & 67 & 6.24 & $1 \mathrm{st}$ \\
\hline
\end{tabular}

Table 16: Problems Encountered by Professional Firms involved in PPP/Variant Procurement

\begin{tabular}{|l|l|l|}
\hline Problems & Frequency & Percentage \% \\
\hline $\begin{array}{l}\text { Poor concession letting method } \\
\text { Lack of preliminaries studies for very technical } \\
\text { concession }\end{array}$ & 22 & 32.8 \\
Absence of candidate pre- selection & 9 & 13.4 \\
Lack of visibility for the basic data given to & 3 & 4.5 \\
tenderers & 7 & 10.4 \\
Ineffective of Legal & 5 & 7.5 \\
Insufficient of Economics & 5 & 7.5 \\
Inadequate of Technology & 11 & 16.5 \\
Poor Environmental & 4 & 6.0 \\
\hline
\end{tabular}


ISSN : 2248-9622, Vol. 7, Issue 5, ( Part -3) May 2017, pp.127-135

\begin{tabular}{|l|l|l|}
\hline Lack of Social & 1 & 1.5 \\
& & \\
\hline Total & $\mathbf{6 7}$ & $\mathbf{1 0 0 . 0}$ \\
\hline
\end{tabular}

Table 17: Benefits Associated with Public Private Partnerships in infrastructure development.

\begin{tabular}{|c|c|c|c|c|c|c|c|c|c|c|c|c|c|c|c|}
\hline \multirow[t]{2}{*}{ Benefits } & \multicolumn{11}{|c|}{ Frequency } & \multirow{2}{*}{$\begin{array}{l}\text { TW } \\
\text { V }\end{array}$} & \multirow[t]{2}{*}{$N$} & \multirow{2}{*}{$\begin{array}{l}\text { MW } \\
\text { V }\end{array}$} & \multirow{2}{*}{$\begin{array}{l}\text { Ran } \\
\mathbf{k}\end{array}$} \\
\hline & $\mathbf{0}$ & 1 & 2 & 3 & 4 & 5 & 6 & 7 & 8 & 9 & 10 & & & & \\
\hline Risk Sharing & 0 & 1 & 1 & 0 & 2 & 5 & 10 & 12 & 13 & 0 & 13 & 414 & 67 & 6.18 & 6th \\
\hline Financial Option & 0 & 1 & 1 & 1 & 1 & 6 & 9 & 18 & 11 & 10 & 10 & 477 & 67 & 7.12 & 2nd \\
\hline $\begin{array}{ll}\begin{array}{l}\text { Construction } \\
\text { Saving }\end{array} & \text { Cost } \\
\end{array}$ & 0 & 1 & 2 & 3 & 4 & 18 & 10 & 7 & 15 & 5 & 4 & 434 & 67 & 6.48 & $3 \mathrm{rd}$ \\
\hline Operation Saving & 0 & 0 & 1 & 4 & 9 & 17 & 13 & 12 & 3 & 3 & 1 & 358 & 67 & 5.34 & 9th \\
\hline Faster Implementation & 0 & 2 & 4 & $\begin{array}{l}1 \\
0\end{array}$ & 12 & 5 & 10 & 8 & 7 & 8 & 1 & 367 & 67 & 5.48 & 8th \\
\hline $\begin{array}{l}\text { Great Performance } \\
\text { Measurement }\end{array}$ & 0 & 1 & 0 & 4 & 10 & 13 & 10 & 8 & 6 & 11 & 4 & 415 & 67 & 6.19 & 5th \\
\hline $\begin{array}{l}\text { Increased Public Sector } \\
\text { Revenue }\end{array}$ & 0 & 0 & 3 & 2 & 0 & 7 & 10 & 11 & 17 & 12 & 5 & 478 & 67 & 7.13 & 1 st \\
\hline $\begin{array}{ll}\text { Enhanced } & \text { Facility } \\
\text { Maintenance } & \\
\end{array}$ & 0 & 2 & 2 & 4 & 1 & 14 & 11 & 15 & 5 & 6 & 7 & 427 & 67 & 6.38 & 4th \\
\hline Innovation Solution & 0 & 2 & 4 & 4 & 7 & 13 & 10 & 7 & 9 & 9 & 2 & 397 & 67 & 5.93 & 7 th \\
\hline
\end{tabular}

\section{Discussion}

The survey and analysis of data carried out, reveals the percentage of analyzed questionnaire to be $67 \%$ and those not returned being $33 \%$, according to Efunkoya (1998), the result of a survey would be biased and of little value if the returned rate was lower than $30-40 \%$. The $67 \%$ returned rate of the total questionnaire can therefore be considered as unbiased for analysis. In order to carry out a detailed research of this kind of study, different respondents in the construction industry should be considered. The relevant respondents such as, architects, quantity surveyors, builders, engineers and other stakeholders who have different educational and professional qualification related to the subject matter were considered. It was observed from the analysis done, that the highest number of respondents is the quantity surveyors followed by the engineers, architects, builders and the others. Also the firms that were considered are the consulting firms, contracting firms and consortium firms. The number of years of experience of the respondents in the construction industry was of great importance to this study because it affects the information that will be supplied.

Nigeria began to use PPP and its variants in the mid to late 1990s. The trend is expected to continue in this decade, with great impact on the private sector and, most importantly, the consumer, (Peter, 2002). This study finds that the form of PPP and its variants is very low among the types of procurement methods adopted in the construction industry. Considering the date earlier stated by Peter, (2002), one would think that by now PPP/Variants should have gained enough ground in the construction industry; from the research carried out by Adeosun, (2008) on Public Private Partnership Procurement in Nigeria construction industry his result, corroborates the present work that the awareness of this procurement method among the participants in Nigeria construction industry was very low. Most respondents to the distributed survey questionnaire have heard of PPP and its variants but not all of them have used it to procure infrastructural development projects. This research shows that of all the variants, Build Operate and Transfer (BOT) has the highest awareness with mean weighted value of 6.78 which is equivalent to $68 \%$; followed by Joint Venture (JV) with mean weighted value of 6.11 which is also equivalent to $61 \%$; Private Finance Initiative (PFI) has mean weighted value of 5.85 which is equivalent to $59 \%$ and only Service Contract among the other variants of PPP has the lowest awareness with mean weighted value of 4.61 which is equivalent to $46 \%$. This confirms that the awareness of PPP and its Variants although low, is still fairly evenly distributed within the construction industry procurement methods. The fair awareness of this method could be related to the fact that Nigeria is still a developing economy and the construction industry is still used to conventional procurement methods of executing projects. Other reasons; being that the actors in the construction industry and relevant government agencies are still to acquire requisite knowledge and experience on PPP/Variants project procurement process as revealed by ICRC (2010). PPP will be a novel arrangement in Nigeria if well understood and followed. For instance, the Muritala 
Mohammed Domestic Airport Terminal 2 project is the first of its kind in the aviation and construction sector of the Nigeria economy.

The benefits of PPP and its variants have been stated by different authors, one of the aims of utilizing this alternative procurement route is to enable the client to obtain value for money. It has also been suggested that selection of an appropriate PPP procurement system for a project would assist government to attain its objectives of cost saving regarding the financing of infrastructure projects.This way, the government would be able to provide adequate infrastructure projects with minimum cost, maximum revenue generated and benefits.

Many authors have discussed the importance of selectingPPP as the most suitable procurement method in infrastructure development.One of the criterion suggested, is price, completion period, and other critical issues such as value for money and it has been widely recognized that by using private sector finance, skills and expertise, service can be procured at a cheaper cost and value for money can be attained. ADB, (2006) recognized an essential benefit of PPP asan incentive delivery solution and not just asset creation; it accelerates programme that is time bound on implementation; it gives measurement of quality and payment linked to service delivery; it gives better overall management of public services and transparency in prioritization. This study supports other researches on the benefits of PPP.Result shows that Increased Public Sector Revenue has the highest mean weighted value MWV (7.13) and was ranked number one benefit of PPP; followed by Financial Option; Construction Cost Saving; Enhanced Facility Maintenance; Great Performance Measurement and Finally Risk Sharing.

Lucy, (2001) opined that one of the aims of utilizing these alternative procurement routes is to enable the client to obtain value for money at appropriate time as earlier mentioned. This investigation was able to analyze if PPP and its variants have any significant effects on project delivery in terms of final construction cost and final construction time and the results arrived at proved these assumptions.

\section{BIBLIOGRAPHY}

[1]. Abdul Quium, (20011). A Guidebook on Public-Private Partnership in Infrastructure: A paper for

[2]. Economic and Social Commission for Asia and the Pacific (pp1-83).

[3]. Adeola, A. (2005).Analysis of the cost of infrastructure failures in a developing economy: The case of theElectricity sector in Nigeria; AERC Research Paper 148, African Economic ResearchConsortium, Nairobi February 2005.
[4]. Adeosun, A.O. (2008). An Appraisal of Public Private Partnership Procurement System in Nigeria: A paper delivered at workshop organized by Nigerian Institute of Quantity Surveyors; Osun State branch, November 2008 (pp. 10-15)

[5]. Alabi, M. and Ocholi, V. (2010).State of Infrastructure and Funding in Kogi State: Nigeria Journal ofSocial Sciences; 2(3): 209-213, 2010 (pp1-5)

[6]. Akewusola, A.O. (2010).The Risks Involved in Public Private Partnership: Being a paper deliveredata seminar/ inter-university competitionObafemi Awolowo University, Ile-Ife, Nigeria; Date: $21^{\text {st }}$ September, 2010.

[7]. Asian Development Bank (ADB 2006). Facilitating Public-Private Partnership for Accelerated

[8]. Infrastructure Development in India: Regional Workshops paper on Public Partnership; (pp. 1-77).

[9]. Babatunde, S.O. Opawole, A., Ujaddughe, I.C. (2010).An Appraisal of Project Procurement Methodin the Nigerian Construction Industry: Civil Engineering Dimension; Vol. 12, No. 1,

[10]. March 2010, 1-7 ISSN 1410-9530 prints / ISSN 1979-570X. (pp. 1-7).

[11]. Bernstein, H. (2003). Underdeveloped and Development: The Third World Today; Suffolk, EnglandClay Ltd. and Federal Government of Nigeria First National Development plan)

[12]. Lagos; Federal Ministry of Information, 2003.

[13]. Broad, W. and Kaul, A. (2005).Global Public-Private Partnerships and the Current Landscape

[14]. Study: Outline article of united national development programme; (pp. 1-8)

[15]. Obozuwa, D. (2011).Public Private Partnership (PPP) as a tool for InfrastructureDevelopment in Nigeria: (pp. 1-13)

[16]. Eduardo, M.R., Engel, H., Ronald, D., Fischer, M., and Alexander, G. (2007).The basic Public Finance ofPublic-Private Partnerships: Yale University Centre Discussion; Paper No. 957, (pp. 1-45), 2007.

[17]. Elisabetta, H.A. (2007).Contract Design in Public-Private Partnerships:Report prepared for the World Bank (pp. 1-101)

[18]. Grahame, A. (2001). The Private Finance Initiative on Infrastructural Development: Article of EconomicPolicy and Statistics; Section Research Paper, 01, 117, 18 December 2001 (pp. 31-40). 
[19]. Infrastructural Concessions Regulatory Commission (ICRC 2010). Nigeria most dynamic Public

[20]. Private Partnership Market in Africa: Paper presented by Head of Monitoring and Compliance Unit ICRC Nigeria; Februarys 2010. (pp. 17-31)

[21]. Kahn, A. (2000). Social Policy and Social Services: 2nd Ed.New York; Random House, NY, 2000.

[22]. Lucy W.C. (2001): Private financing of Construction Project and Procurement Systems: AnIntegratedApproach; CIB World Building Congress, Wellington, New Zealand, paperNumber 259, April 2001. (pp. 1-6).

[23]. Matson, P. (2006). Role of Public Private Partnership in Infrastructure Development: Article on howPublic Private Partnerships Work; (pp. 3-5).

[24]. Odusami, K.T. and Kadiri, D.S. (2007).Comparative Study of Time and Cost Performance of DirectLabour and Labour Only Procurement systems: Journal of Nigerian Institute of

[25]. Quantity Surveyor; Volume44, No 3, JulySeptember, 2007, (pp. 1-40)

[26]. Organization for Economic Co-operation and Development (OECD, 2007). Infrastructure to 2030: Organization forEconomic Co-operation and Development; Volume 2,(pp. 510-13).

[27]. Odusami, K. T. and Adetola E.A. (2006). Factor Affecting the selection of Project Procurement Methods: Building Magazine; April-May 12(1), pp. 11-16

[28]. Ohia, S., (2011). Infrastructure Concession in Nigeria: Challenges and Opportunities;A paper Presented at the 5th National Diaspora Conference 2011 Diaspora day Held at the Congress hall, Transcorp Hilton Hotel Abuja 25-27 July, 2011(pp. 1-22)

[29]. Olayiwola and Adeleye (2005). Rural Infrastructure Development in Nigeria Problem and Challenge (pp.1-6).

[30]. Oyodele, A., (2012).The Challenges of Infrastructure Development in Democratic Governance. (pp. 1-15)

[31]. Patrick, B., (2007). Proceeding to Transport, Infrastructure Development for a wide, Seminar, Paris, November 27-28, 2007

[32]. Peter, G.R. (2002): Enhancing Development in Africa: Public- private Partnership, the African Development Bank Group, and March, 2002. (pp. 9-11)

[33]. Ramus, J. (2006) Contract Practices for surveyor fourth edition:ButterworthHeinemann Print; (43-457)
[34]. Salah Darghouth, (2007).Emerging PublicPrivate Partnerships in Irrigation Development and Management:Water Sector Board Discussion Paper; Series Paper, No12, 10 May 2007 (pp. 1-60)

[35]. Sharon, A. H., (2001). A Guide to Successful Public-Private Partnerships for out of School timeandCommunity Schoolinitiatives; article on finance project (pp. 1-43)

[36]. Solomon, T. (2006).Public Private Partnerships and Build Operate and Transfer (BOT) and suchlikeSchemes:A Sessional paper for Pacific Island Forum Secctretariat; Forum EconomicMinisters Meeting July 2006 (pp. 1-17)

[37]. Techgrade, G. (2007).Procedure for Managing the Construction Phase of BOT Contracts:PaperPresented at a 3-Day Workshop on Formation and Management of Build-

[38]. Operate Transfer (BOT) Contracts; Organized by Techgrade Consulting, (pp.110)

[39]. United Nation Economic Commission for Europe UNECE (2001).Guidelines on Private Public

[40]. Partnerships for Infrastructure Development: Article of public-private partnerships forInfrastructure; The next steps (PPP) pp. $1-102$

[41]. Economic and Social Commission for Asia and the Pacific ESCAP (2009). Definitions of InfrastructureFor the purposes of the Americas Recovery and Reinvestment: Economic and SocialCommission for Asia and the Pacific; (pp. 1-8).

[42]. Vellez, H., Spagnolo, P., and Iossa, T. (2007).Contract Design in Public Private Partnership: Report paper forWorld Bank; (pp. 1-101).

[43]. Victor, E. D., (2010). Review of the Challenges Facing the Nigerian Economy: Journal of SustainableDevelopment in Africa; Volume 12, No.5, 2010, (pp. 1-18). 